\title{
Increasing mean arterial blood pressure in sepsis: effects on fluid balance, vasopressor load and renal function
}

Thiago Domingos Corrêa ${ }^{1 \dagger}$, Madhusudanarao Vuda ${ }^{1 \dagger}$, Jukka Takala', Siamak Djafarzadeh, Eliézer Silva² and Stephan Mathias Jakob ${ }^{1 *}$

\begin{abstract}
Introduction: The objective of this study was to evaluate the effects of two different mean arterial blood pressure (MAP) targets on needs for resuscitation, organ dysfunction, mitochondrial respiration and inflammatory response in a long-term model of fecal peritonitis.
\end{abstract}

Methods: Twenty-four anesthetized and mechanically ventilated pigs were randomly assigned ( $n=8 / g r o u p)$ to a septic control group (septic-CG) without resuscitation until death or one of two groups with resuscitation performed after 12 hours of untreated sepsis for 48 hours, targeting MAP 50-60 mmHg (low-MAP) or 75-85 mmHg (high-MAP).

Results: MAP at the end of resuscitation was $56 \pm 13 \mathrm{mmHg}$ (mean \pm SD) and $76 \pm 17 \mathrm{mmHg}$ respectively, for low-MAP and high-MAP groups. One animal each in high- and low-MAP groups, and all animals in septic-CG died (median survival time: 21.8 hours, inter-quartile range: 16.3-27.5 hours). Norepinephrine was administered to all animals of the high-MAP group $(0.38(0.21-0.56) \mathrm{mcg} / \mathrm{kg} / \mathrm{min})$, and to three animals of the low-MAP group $(0.00(0.00-0.25) \mathrm{mcg} / \mathrm{kg} /$ min; $P=0.009)$. The high-MAP group had a more positive fluid balance $(3.3 \pm 1.0 \mathrm{~mL} / \mathrm{kg} / \mathrm{h}$ vs. $2.3 \pm 0.7 \mathrm{~mL} / \mathrm{kg} / \mathrm{h} ; P=$ 0.001). Inflammatory markers, skeletal muscle ATP content and hemodynamics other than MAP did not differ between low- and high-MAP groups. The incidence of acute kidney injury (AKI) after 12 hours of untreated sepsis was, respectively for low- and high-MAP groups, 50\% (4/8) and 38\% (3/8), and in the end of the study 57\% (4/7) and 0\% (P=0.026). In septic-CG, maximal isolated skeletal muscle mitochondrial Complex I, State 3 respiration increased from $1357 \pm 149$ $\mathrm{pmol} / \mathrm{s} / \mathrm{mg}$ to $1822 \pm 385 \mathrm{pmol} / \mathrm{s} / \mathrm{mg}$, $(P=0.020)$. In high- and low-MAP groups, permeabilized skeletal muscle fibers Complex IV-state 3 respiration increased during resuscitation $(P=0.003)$.

Conclusions: The MAP targets during resuscitation did not alter the inflammatory response, nor affected skeletal muscle ATP content and mitochondrial respiration. While targeting a lower MAP was associated with increased incidence of AKI, targeting a higher MAP resulted in increased net positive fluid balance and vasopressor load during resuscitation. The long-term effects of different MAP targets need to be evaluated in further studies.

\section{Introduction}

The arterial blood pressure is the driving force to blood flow through the tissues. According to the principle of blood flow autoregulation, if cardiac output is constant, blood flow to tissues does not change until blood pressure falls below a critical value. When this autoregulatory

\footnotetext{
* Correspondence: stephan.jakob@insel.ch

+ Contributed equally

'Department of Intensive Care Medicine, Inselspital, Bern University Hospital and University of Bern, Freiburgstrasse 10, Bern, CH-3010, Switzerland

Full list of author information is available at the end of the article
}

threshold is reached, any additional decrease in arterial blood pressure levels will compromise organ blood flow [1].

The Surviving Sepsis Campaign Guidelines recommend a mean arterial blood pressure (MAP) higher than 65 $\mathrm{mmHg}$ during the initial resuscitation of severe sepsis and septic shock [2]. However, there is only weak evidence to support this recommendation.

Few small prospective clinical studies have addressed the effects of different MAP levels on tissue perfusion in
Ciomed Central

C 2012 Corrêa et al.; licensee BioMed Central Ltd. This is an open access article distributed under the terms of the Creative Commons Attribution License (http://creativecommons.org/licenses/by/2.0), which permits unrestricted use, distribution, and reproduction in any medium, provided the original work is properly cited. 
septic shock [3-6]. Increasing MAP from 65 to $85 \mathrm{mmHg}$ has not been shown to improve systemic oxygen metabolism, splanchnic perfusion or renal function, has had inconsistent effects on local microcirculation, and has been associated with higher left ventricular stroke work index and increased exposure to norepinephrine $[3,4,6]$. Apart from influencing systemic and regional perfusion and organ blood flow distribution $[7,8]$, vasopressors may also affect the balance between oxygen and substrate supply and metabolic needs [9], with the potential to affect mitochondrial function [10], which has been associated with organ failure and poor outcome during sepsis [11-13]. Furthermore, in clinical practice as well as in research, the actual blood pressure achieved is often markedly higher than the targets originally prescribed [14], resulting in unnecessary and potentially harmful, further exposure to fluids and catecholamines [15].

The optimal balance between arterial blood pressure goals and minimal side-effects of fluids and drugs needs to be determined [16]. On one hand, aiming for higher MAP levels during the initial resuscitation of patients in septic shock increases the exposure to fluids, vasopressors and inotropes, which has been associated with increased mortality [15]. On the other hand, targeting lower levels of MAP may increase the incidence of tissue hypoperfusion and contribute to progression of organ failure [17-19].

The aim of this experimental study was to evaluate the impact of two different levels of MAP, namely between 50 and $60 \mathrm{mmHg}$ (low-MAP) or between 75 and 85 $\mathrm{mmHg}$ (high-MAP), on the need for resuscitation, sepsisassociated organ dysfunction, mitochondrial respiration and inflammatory response in a long-term model of fecal peritonitis.

\section{Materials and methods}

This study was performed in accordance with the National Institutes of Health guidelines for the care and use of experimental animals and with the approval of the Animal Care Committee of the Canton Bern, Switzerland.

Twenty-four domestic pigs of both sexes (mean weight \pm SD $41.0 \pm 3.1 \mathrm{~kg}$ ) were fasted for 12 hours prior to the experiment, with free access to water. The pigs were sedated with intramuscular ketamine $(20 \mathrm{mg} / \mathrm{kg})$ and xylazine $(2 \mathrm{mg} / \mathrm{kg})$. A peripheral intravenous catheter was inserted in an ear vein for administration of fluids and drugs. Pigs were orally intubated following induction of anesthesia with midazolam $(0.5 \mathrm{mg} / \mathrm{kg})$ and atropine $(0.02 \mathrm{mg} / \mathrm{kg})$. Anesthesia was maintained with propofol $(4 \mathrm{mg} / \mathrm{kg} / \mathrm{h})$ and fentanyl $(5 \mu \mathrm{g} / \mathrm{kg} / \mathrm{h}$ during surgery and $2 \mu \mathrm{g} / \mathrm{kg} / \mathrm{h}$ afterwards). When necessary, additional injections of fentanyl $(50 \mu \mathrm{g})$ or midazolam $(5 \mathrm{mg})$ were administered. The stomach was kept empty by insertion of a large-bore orogastric tube.
Animals were ventilated in a volume-controlled mode with a positive end-expiratory pressure (PEEP) of $5 \mathrm{~cm}$ $\mathrm{H}_{2} \mathrm{O}$, a fractional inspiratory oxygen concentration $\left(\mathrm{FiO}_{2}\right)$ of $30 \%$, and a tidal volume of $8 \mathrm{~mL} / \mathrm{kg}$ (Servo-i ${ }^{\circledR}$, Maquet Critical Care, Solna, Sweden). The respiratory rate was adjusted aiming an arterial carbon dioxide partial pressure $\left(\mathrm{PaCO}_{2}\right)$ between 35 and $45 \mathrm{mmHg}$.

\section{Surgical preparation}

The right jugular vein was cannulated via a midline cervical incision for a pulmonary artery catheter placement. A double lumen catheter was placed into the left femoral vein. An arterial catheter for blood pressure measurement and blood sampling was placed into the right carotid artery. Ultrasound Doppler 4-mm flow probes (Transonic ${ }^{\circledR}$ Systems Inc., Ithaca, NY, USA), which had previously been calibrated in vitro, were placed around the left carotid artery and the left femoral artery. With the pig in the supine position, a midline mini-laparotomy was performed and a large-bore intra-peritoneal drain inserted. After preparation, the abdominal incision was closed. Finally, cystostomy was performed for drainage of urine. Throughout the surgical preparation, Ringer's lactate was infused at $3 \mathrm{~mL} / \mathrm{kg} / \mathrm{h}$.

\section{Study protocol}

After surgical preparation, animals were stabilized for $6 \mathrm{~h}$ and Ringer's lactate and glucose 50\% (G50\%) were infused (adding up to $1.5 \mathrm{~mL} / \mathrm{kg} / \mathrm{h}$ ) and adjusted to keep blood glucose in the range of 3.5 to $5.0 \mathrm{mmol} / \mathrm{L}$. Then, baseline measurements were performed and pigs were randomly assigned ( $\mathrm{n}=8$ per group) to a septic control group (septic-CG) without resuscitation until death, or to one of two groups in which resuscitation was performed after $12 \mathrm{~h}$ of untreated sepsis for $48 \mathrm{~h}$, targeting MAP between 50 and $60 \mathrm{mmHg}$ (low-MAP) or between 75 and $85 \mathrm{mmHg}$ (high-MAP) (Figure 1). Fecal peritonitis was induced by peritoneal instillation of $2 \mathrm{~g} / \mathrm{kg}$ body weight of autologous feces dissolved in $250 \mathrm{~mL}$ warmed glucose $5 \%$ solution. Afterwards, the intra-peritoneal drain remained clamped throughout the experiment.

After $12 \mathrm{~h}$ of untreated sepsis (observation period), animals randomized to the low- and high-MAP groups were submitted to $48 \mathrm{~h}$ of protocolized resuscitation (resuscitation period) conducted by trained intensivists (Additional file 1). Alternating boluses of $150 \mathrm{~mL}$ Ringer's lactate and 6\% hydroxyethyl starch (130/0.4) were administered when signs of hypovolemia became evident. Fluid boluses were repeated as long as the stroke volume was increased by $10 \%$ or more after fluid administration. The maximum dose of hydroxyethyl starch administered during the study was $30 \mathrm{~mL} / \mathrm{kg}$. After this maximal dose was reached, only boluses of Ringer's lactate were given. If the mixed venous 


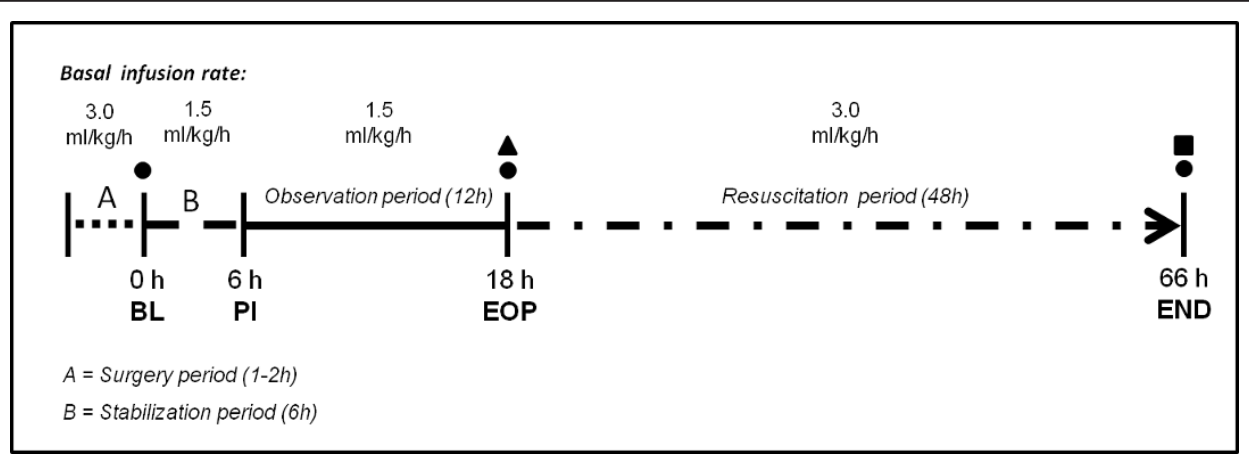

Figure 1 Study design for the low and high mean arterial pressure (MAP) groups. Black circles, samples from the right quadriceps muscle to assess mitochondrial function and quantification of skeletal muscle ATP content; black triangle, first dose of intravenous antibiotic (piperacillin/tazobactam, $2.25 \mathrm{~g}$, 8-hourly); black square, additional tissue samples from the liver for mitochondrial function analysis at the end of the experiment ( $66 \mathrm{~h}$ or before death, if earlier). Animals allocated to the septic control group (Septic-CG) were followed without resuscitation after induction of peritonitis until death. BL, baseline; Pl, peritonitis induction; EOP, end of observation period (before starting resuscitation); End, end of the experiment (at 48 hours of resuscitation or before death if earlier.

oxygen saturation $\left(\mathrm{SvO}_{2}\right)$ was lower than $50 \%$, dobutamine administration was started at a dose of $5.0 \mathrm{mg} / \mathrm{h}$. This dose was increased by $5.0 \mathrm{mg} / \mathrm{h}$ every 30 minutes until the $\mathrm{SvO}_{2}$ was $50 \%$ or higher, or until a maximal dose of 20 $\mathrm{mg} / \mathrm{h}$ was given. If the MAP was below $50 \mathrm{mmHg}$ in the low-MAP group and $75 \mathrm{mmHg}$ in the high-MAP group, norepinephrine was administrated (Figure S1 in Additional file 2).

After resuscitation was started, all animals in the lowand high-MAP groups received intravenous (i.v.) administration of piperacillin-tazobactam $\left(\right.$ Tazobac $^{\mathbb{B}}$ ) $2.25 \mathrm{~g}$, every $8 \mathrm{~h}$, and deep vein thrombosis prophylaxis (continuous i.v. infusion of 10,000 IU of non-fractionated heparin/24 h) (Figure 1). Details on respiratory care and ventilator settings can be found in Additional file 1. Following $48 \mathrm{~h}$ of resuscitation, study animals were deeply sedated and euthanized with an overdose of potassium chloride.

A basal fluid supply of $1.5 \mathrm{~mL} / \mathrm{kg} / \mathrm{h}$ during the observation period and $3.0 \mathrm{~mL} / \mathrm{kg} / \mathrm{h}$ during the resuscitation period was given as Ringer's lactate and G50\%, adjusted to maintain blood glucose in the range of 3.5 to $5.0 \mathrm{mmol} / \mathrm{L}$.

\section{Monitoring}

Hemodynamics, temperature and respiratory parameters were monitored throughout the study, using a multi-modular patient monitor (S/5 Critical Care Monitor ${ }^{\mathbb{B}}$; DatexOhmeda, GE Healthcare, Helsinki, Finland). Thermodilution cardiac output ( $\mathrm{L} /$ minute), mixed venous oxygen saturation $\left(\mathrm{SvO}_{2}\right)\left(\right.$ Vigilance ${ }^{\circledR}$; Edwards Lifesciences LLC, Irvine, CA, USA), and carotid and femoral artery blood flows (TS 420 double-channel flowmeters, Transonic Systems Inc.) were continuously measured. Data were recorded in software for data acquisition and signal analysis (Soleasy ${ }^{\mathrm{TM}}$, National Instruments Corp., Austin, TX, USA), and in an electronic patient data management system (Centricity Clinisoft ${ }^{\mathbb{R}}$; GE Healthcare).

\section{Blood sampling}

Techniques and time points of blood sampling for determination of blood gases, arterial lactate, electrolytes, hemoglobin, platelets, white blood cell count, serum creatinine, total bilirubin, creatine-kinase, troponin, plasma IL- 6 andTNF- $\alpha$ are described in Additional file 1.

\section{Mitochondrial function analysis}

Right quadriceps muscle samples were taken to assess isolated skeletal muscle, mitochondrial function of permeabilized skeletal muscle fibers, and for the quantification of skeletal muscle, ATP content. Isolation of skeletal muscle, liver mitochondria and mitochondrial oxygen consumption (by high-resolution respirometry) were performed as described previously [20]. An additional tissue sample was taken from the left lobe of the liver at the end of the experiment (Figure 1). Preparation of permeabilized muscle fibers is described in detail in Additional file 1.

In septic-CG, respiration of isolated skeletal muscle mitochondria and permeabilized skeletal muscle fibers was assessed at baseline, and before death occurred (end). In the low- and high-MAP groups, isolated skeletal muscle mitochondria and permeabilized skeletal muscle fibers mitochondrial respiration were measured at baseline, end of the observation period (EOP; before starting resuscitation) and at the end of the experiment (END). In animals that died earlier, the final samples were taken when the animals were still alive and receiving the maximal norepinephrine dose of 5,000 $\mathrm{mcg} / \mathrm{h}$, and when MAP approached $30 \mathrm{mmHg}$. Skeletal muscle ATP content was quantified using a luciferase-based ATP determination kit (A22066, Molecular Probes, Eugene, OR, USA).

\section{Calculations and acute kidney injury definition}

Systemic oxygen delivery $\left(\mathrm{DO}_{2} ; \mathrm{mL} / \mathrm{min}\right)$ and consumption $\left(\mathrm{VO}_{2} ; \mathrm{mL} / \mathrm{min}\right)$ were calculated using cardiac output 
and arterial and mixed venous blood gases, according to standard formulas (Additional file 1). Acute kidney injury (AKI) was defined according to the AKIN criteria as an increase of more than $0.3 \mathrm{mg} / \mathrm{dl}(26.4 \mu \mathrm{mol} / \mathrm{L})$ or $150 \%$ in serum creatinine from the baseline measurement [21]. Percentage of time below or above a certain blood pressure was calculated using 2-minute median-filtered values.

\section{Statistical analysis}

All data are presented as mean \pm standard deviation (SD), or median with IQR in the case of non-normal distribution (tested by the Kolmogorov-Smirnov test). All baseline data, fluids, vasoactive drugs, sedation, fluid balance, creatinekinase, troponin, liver mitochondrial respiration and skeletal muscle ATP content were compared between groups using one-way analysis of variance (ANOVA) followed by the Tukey or independent samples $t$-test. Binary variables were analyzed with Fisher's exact test and survival proportions between groups were analyzed with the log rank test.

Differences between groups in the evolution over time were assessed by ANOVA for repeated measurements using group as the between-subject factor and time as the within-subject factor. This was done first for all three groups, using baseline, EOP and end values. Afterwards, the same procedure was repeated for the low- and highMAP groups only, but including all measurements (baseline, EOP, 12, 24, 36 and 48 h). If a time-group interaction was detected between the low- and high-MAP groups, the independent samples $t$-test was performed at the end of the experiment (at $48 \mathrm{~h}$ of resuscitation, or before death if earlier). In the case of non-normal distribution of study variables, time effect was separately measured within each group using the non-parametric Friedman's test. At the EOP and at the end of the experiment, all study groups were compared with Kruskal-Wallis test, and the low- and high-MAP groups were compared with Mann-Whitney $U$-test, in the case of a significant Kruskal-Wallis test. A potential relationship between time spent below/above different blood pressure levels expressed as percent, or being administered fluids, and end plasma creatinine concentrations/diuresis was evaluated using Spearman's correlation. The paired $t$-test was performed to compare baseline to end in the septic-CG.

A $P$-value $<0.05$ was considered significant. The Statistical Package for Social Sciences (SPSS) version 20.0 (SPSS Inc. ${ }^{\circledR}$; Chicago, IL, USA) was used for statistical analysis.

\section{Results}

\section{Mortality}

All animals in the septic-CG died, with a median survival time of $21.8 \mathrm{hs}$ (16.3 to $27.5 \mathrm{~h}$ ). One animal each in the low- and high-MAP groups died during the resuscitation period, respectively, after 38 and $19.5 \mathrm{~h}$ of induction of peritonitis (Figure 2).

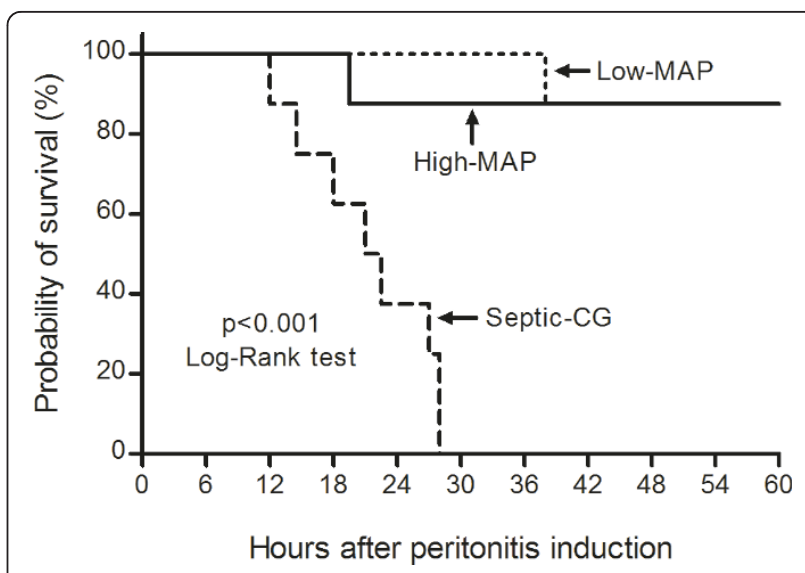

Figure 2 Kaplan-Meyer survival curve. MAP, mean arterial pressure; Septic-CG, septic control group.

\section{Treatment intensity}

The high-MAP group tended to receive more fluid boluses than the low-MAP group $(P=0.06)$ and had higher cumulative fluid balance at study end $(P=0.001)$ (Table 1). During the resuscitation period, norepinephrine was administered to $3 / 8$ animals $(37.5 \%)$ in the lowMAP group and to all animals in the high-MAP Group $(P=0.026)$ (Table 1; see also Figure S1 in Additional file 2). Dobutamine was administered to $4 / 8$ animals (50.0\%) in the low-MAP and to $3 / 8$ animals $(37.5 \%)$ in the high-MAP group $(P=1.0)$. Doses of administered norepinephrine and dobutamine are shown in Table 1.

\section{Hemodynamics, oxygen transport, respiratory and acid- base variables}

MAP at the end of the resuscitation period was $56 \pm 13$ $\mathrm{mmHg}$ and $76 \pm 17 \mathrm{mmHg}$ respectively, for the low- and high-MAP groups (Table 2). During the resuscitation period, blood pressure attained overlapped to a certain extent between the groups: in the low-MAP animals it was $\geq 75$ $\mathrm{mmHg}$ during $27.5 \%$ of the time, while it was $<75 \mathrm{mmHg}$ in the high-MAP group during $8.1 \%$ of the time (Table S1 in Additional file 2). None of the other hemodynamic parameters, systemic oxygen delivery, consumption, or arterial lactate differed between the low- and high-MAP groups (Table 2). Arterial pH, bicarbonate, base excess, $\mathrm{PaCO}_{2}$, minute ventilation, ratio of arterial oxygen partial pressure to fraction of inspired oxygen and PEEP did not differ between the low- and high-MAP groups (Table S2 in Additional file 2).

\section{Inflammatory markers and organ function parameters}

IL- 6 and TNF- $\alpha$ plasma levels increased from baseline to the EOP in both the low- and high-MAP groups, and decreased during the resuscitation period (Table 3). Platelets, white blood cell count, bands, metamyelocytes, total 
Table 1 Administered treatment, fluid output and balance during the study

\begin{tabular}{|c|c|c|c|c|}
\hline Variables/Study group & $\begin{array}{l}\text { Septic- } \\
\text { CG }\end{array}$ & $\begin{array}{l}\text { Low- } \\
\text { MAP }\end{array}$ & $\begin{array}{l}\text { High- } \\
\text { MAP }\end{array}$ & $\begin{array}{c}P- \\
\text { value }\end{array}$ \\
\hline Propofol, mg/kg/h & $5.0 \pm 1.0$ & $5.8 \pm 0.7$ & $5.8 \pm 0.5$ & $0.11^{\mathrm{a}}$ \\
\hline Fentanyl, mcg/kg/h ${ }^{\dagger}$ & $4.0 \pm 1.6$ & $3.9 \pm 0.8$ & $4.4 \pm 0.9$ & $0.62^{\mathrm{a}}$ \\
\hline Midazolam, mg/kg/h & $\begin{array}{c}0.08 \pm \\
0.03\end{array}$ & $\begin{array}{c}0.06 \pm \\
0.02\end{array}$ & $\begin{array}{c}0.07 \pm \\
0.04\end{array}$ & $0.38^{\mathrm{a}}$ \\
\hline \multicolumn{5}{|l|}{ Fluid bolus, $\mathrm{mL} / \mathrm{kg} / \mathrm{h}^{\dagger+*}$} \\
\hline Median & & 0.7 & 2.0 & $0.06^{b}$ \\
\hline IQR & & $0.5,2.0$ & $1.6,2.8$ & \\
\hline \multicolumn{5}{|l|}{ Norepinephrine } \\
\hline $\begin{array}{l}\text { Number/number in group } \\
(\%)\end{array}$ & & $3 / 8(37.5)$ & $\begin{array}{c}8 / 8 \\
(100.0)\end{array}$ & $0.026^{c}$ \\
\hline Median dose, mcg $/ \mathrm{kg} / \mathrm{min}$ & & 0.00 & 0.38 & $0.009^{b}$ \\
\hline IQR & & $0.00,0.25$ & $0.21,0.56$ & \\
\hline \multicolumn{5}{|l|}{ Dobutamine } \\
\hline $\begin{array}{l}\text { Number/number in group } \\
(\%)\end{array}$ & & $4 / 8(50.0)$ & $3 / 8(37.5)$ & $1.00^{c}$ \\
\hline Median dose, mcg $/ \mathrm{kg} / \mathrm{min}$ & & 0.06 & 0.00 & $0.45^{\mathrm{b}}$ \\
\hline IQR & & $0.00,3.16$ & $0.00,1.00$ & \\
\hline $\begin{array}{l}\text { Total volume received, mL/ } \\
\mathrm{kg} / \mathrm{h}\end{array}$ & $1.5 \pm 0.0$ & $3.6 \pm 0.8^{\S}$ & $4.7 \pm 1.4^{\#}$ & $0.001^{\mathrm{a}}$ \\
\hline Urine output, $\mathrm{mL} / \mathrm{kg} / \mathrm{h}$ & $0.6 \pm 0.1$ & $1.0 \pm 0.2^{\S}$ & $1.1 \pm 0.2^{\#}$ & $0.001^{a}$ \\
\hline $\begin{array}{l}\text { Gastric tube output, mL/kg/ } \\
\text { h }\end{array}$ & $0.3 \pm 0.2$ & $0.3 \pm 0.3$ & $0.3 \pm 0.2$ & $0.95^{\mathrm{a}}$ \\
\hline Final balance ${ }^{\#}, \mathrm{~mL} / \mathrm{kg} / \mathrm{h}$ & $0.6 \pm 0.3$ & $2.3 \pm 0.7^{\S}$ & $3.3 \pm \underset{¥}{*} .0^{\#}$ & $0.001^{\mathrm{a}}$ \\
\hline Final balance\#, L & $0.5 \pm 0.4$ & $5.2 \pm 1.1^{\S}$ & 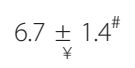 & $0.001^{\mathrm{a}}$ \\
\hline
\end{tabular}

Values are mean \pm SD or median (IQR) unless stated otherwise. ${ }^{\dagger}$ Sum of basic fentanyl infusion with additional boluses; *administered during the 48-h resuscitation period; ${ }^{+t}$ sum of Ringer's lactate and hydroxyethyl starch; ${ }_{\text {final }}$ balance $=($ Ringer's Lactate basal infusion + glucose $50 \%$ basal infusion + Ringer's lactate bolus + hydroxyethyl starch bolus) - (urine output + gastric tube output); a one-way analysis of variance (ANOVA). Tukey post hoc test after ANOVA, comparisons significant at the 0.05 level: ${ }^{*}$ low-mean arterial pressure (MAP) versus high-MAP; ${ }^{\S}$ low-MAP versus septic control group (Septic-CG); " high-MAP versus Septic-CG; ${ }^{b}$ Mann-Whitney test; ${ }^{C}$ Fisher's exact test.

bilirubin, creatine-kinase and troponin did not differ between the low- and high-MAP groups at study end (Table 3). However, animals allocated to low-MAP exhibited a higher median plasma creatinine level than animals in the high-MAP group $(P=0.021)$ (Table 3; see also Figure S2 in Additional file 2). The incidence of AKI after $12 \mathrm{~h}$ of untreated sepsis was, respectively for the low- and high-MAP groups, 50\% (4/8) and 38\% (3/8) $(P=1.00)$. At the end of the study, 57\% (4/7) in the low-MAP group and none in the high-MAP group had AKI $(P=0.026)$.

\section{Mitochondrial function}

\section{Isolated skeletal muscle mitochondrial function}

In the septic-CG, maximal skeletal muscle mitochondrial respiration (complex I-state 3) increased (baseline mean \pm SD $1357 \pm 149 \mathrm{pmol} / \mathrm{s} / \mathrm{mg}$; end $1822 \pm 385 \mathrm{pmol} / \mathrm{s} / \mathrm{mg}$, paired $t$-test: $P=0.020)$, whereas complex I-state 4 and respiratory control ratio (RCR) (Figure 3a), and complex II- and IV-dependent skeletal muscle mitochondrial respiration did not change (Figure $3 \mathrm{~b}, \mathrm{c}$ ). There were no changes over time or differences between the low- and high-MAP groups in the respiration of isolated muscle mitochondria (Figure S3 in Additional file 2).

\section{Isolated liver mitochondrial function}

No significant differences between groups were observed for complex I-, II- or IV-dependent respirations of isolated liver mitochondria (Figure 4).

\section{Permeabilized skeletal muscle fibers mitochondrial function}

Permeabilized skeletal muscle fibers complex I- and II-dependent respiration did not change in the lowand high-MAP groups (Table S3 in Additional file 2). However, complex IV-state 3 respiration increased in the low- and high-MAP groups during the resuscitation period $(P=0.003$ for time effect) with no difference between the groups (Table S3 in Additional file 2). Permeabilized skeletal muscle fibers respiration did not change in the septic-CG (Table S4 in Additional file 2).

\section{Skeletal muscle ATP content}

Skeletal muscle ATP content was preserved in all groups (Figure 5).

\section{Discussion}

Blood pressure targets did not modify mitochondrial respiration or markers of inflammation. However, animals in the low-MAP group had lower $\mathrm{SvO}_{2}$ and hemoglobin levels, and a higher incidence of AKI, while animals in the high-MAP group had increased net positive fluid balance and vasopressor load during resuscitation. If the animals were not resuscitated after $12 \mathrm{~h}$ they died, with increased plasma levels of inflammatory markers, increased maximal skeletal muscle complex I mitochondrial respiration, and with preserved skeletal muscle ATP content.

Few clinical studies have prospectively addressed the effect on disease severity and the development of sepsisassociated organ dysfunction of different levels of MAP during the initial phase of severe sepsis and septic shock resuscitation [3-6]. The lack of available data supporting a specific MAP target during the initial resuscitation of septic patients is emphasized by the wide range of MAP goals (60 to $100 \mathrm{mmHg}$ ) applied in randomized controlled clinical trials [16]. Furthermore, experimental studies in sepsis either do not include MAP targets in resuscitation algorithms [22-24], or set the MAP target at $65 \mathrm{mmHg}$ $[25,26]$, consistent with the current recommendation of the Surviving Sepsis Campaign [2]. Nevertheless, no clinical or experimental studies have prospectively addressed 
Table 2 Systemic and regional hemodynamics and arterial lactate level

\begin{tabular}{|c|c|c|c|c|c|c|c|c|c|}
\hline Variable & Group & BL & EOP & $\mathrm{RP} 12 \mathrm{~h}$ & RP $24 \mathrm{~h}$ & RP $36 \mathrm{~h}$ & RP 48h & END & $P$-value \\
\hline MAP, & Septic-CG & $78 \pm 9$ & $68 \pm 22$ & & & & & $29 \pm 4$ & $<0.001^{\mathrm{a}}$ \\
\hline \multirow[t]{2}{*}{$\mathrm{mm} \mathrm{Hg}$} & LOW-MAP & $65 \pm 9$ & $81 \pm 16$ & $72 \pm 13$ & $67 \pm 12$ & $61 \pm 6$ & $59 \pm 8$ & $56 \pm 13$ & $<0.001^{\mathrm{a}}$ \\
\hline & High-MAP & $63 \pm 7$ & $76 \pm 11$ & $86 \pm 5$ & $81 \pm 7$ & $82 \pm 4$ & $82 \pm 3$ & $76 \pm 17$ & \\
\hline Heart rate, & Septic-CG & $104 \pm 17$ & $193 \pm 41$ & & & & & $216 \pm 25$ & $<0.001^{a}$ \\
\hline \multirow[t]{2}{*}{ beats/minute } & LOW-MAP & $93 \pm 11$ & $166 \pm 23$ & $165 \pm 14$ & $156 \pm 23$ & $141 \pm 28$ & $122 \pm 28$ & $130 \pm 46$ & $0.84^{b}$ \\
\hline & High-MAP & $105 \pm 23$ & $173 \pm 31$ & $163 \pm 22$ & $155 \pm 31$ & $138 \pm 28$ & $117 \pm 29$ & $117 \pm 29$ & \\
\hline MPAP, & Septic-CG & $12 \pm 2$ & $16 \pm 3$ & & & & & $11 \pm 2$ & $<0.001^{\mathrm{a}}$ \\
\hline \multirow[t]{2}{*}{$\mathrm{mm} \mathrm{Hg}$} & LoW-MAP & $15 \pm 3$ & $18 \pm 2$ & $20 \pm 5$ & $21 \pm 5$ & $23 \pm 6$ & $23 \pm 5$ & $23 \pm 4$ & $0.19^{\mathrm{b}}$ \\
\hline & High-MAP & $13 \pm 1$ & $18 \pm 3$ & $19 \pm 2$ & $21 \pm 1$ & $24 \pm 2$ & $24 \pm 3$ & $27 \pm 9$ & \\
\hline CVP, & Septic-CG & $1 \pm 1$ & $1 \pm 1$ & & & & & $0 \pm 1$ & $<0.001^{\mathrm{a}}$ \\
\hline \multirow[t]{2}{*}{$\mathrm{mm} \mathrm{Hg}$} & LOW-MAP & $4 \pm 2$ & $2 \pm 2$ & $3 \pm 2$ & $5 \pm 3$ & $7 \pm 4$ & $8 \pm 4$ & $9 \pm 4$ & $0.41^{\mathrm{b}}$ \\
\hline & High-MAP & $2 \pm 1$ & $1 \pm 1$ & $3 \pm 2$ & $6 \pm 1$ & $7 \pm 1$ & $9 \pm 2$ & $10 \pm 3$ & \\
\hline SVRI, & Septic-CG & $692 \pm 129$ & $966 \pm 197$ & & & & & $600 \pm 238$ & $0.082^{a}$ \\
\hline $\mathrm{mm} \mathrm{Hg}$ & Low-MAP & $589 \pm 60$ & $923 \pm 203$ & $668 \pm 131$ & $451 \pm 131$ & $373 \pm 56$ & $349 \pm 92$ & $319 \pm 119$ & $0.19^{b}$ \\
\hline $\mathrm{L} / \mathrm{Kg} / \mathrm{min}$ & High-MAP & $553 \pm 87$ & $1017 \pm 304$ & $698 \pm 114$ & $525 \pm 185$ & $488 \pm 109$ & $510 \pm 107$ & $475 \pm 140$ & \\
\hline Cardiac & Septic-CG & $115 \pm 27$ & $70 \pm 21$ & & & & & $53 \pm 19$ & $<0.001^{\mathrm{a}}$ \\
\hline index, & Low-MAP & $105 \pm 13$ & $88 \pm 22$ & $104 \pm 13$ & $143 \pm 31$ & $145 \pm 13$ & $149 \pm 19$ & $150 \pm 18$ & $0.38^{b}$ \\
\hline $\mathrm{mL} / \mathrm{kg} / \mathrm{min}$ & High-MAP & $112 \pm 23$ & $77 \pm 16$ & $122 \pm 29$ & $165 \pm 78$ & $160 \pm 36$ & $150 \pm 31$ & $142 \pm 35$ & \\
\hline $\mathrm{SvO}_{2}$ & Septic-CG & $59 \pm 8$ & $53 \pm 12$ & & & & & $35 \pm 11$ & $0.001^{a}$ \\
\hline \multirow[t]{2}{*}{$\%$} & LOW-MAP & $48 \pm 2$ & $56 \pm 9$ & $58 \pm 9$ & $56 \pm 9$ & $60 \pm 6$ & $61 \pm 7$ & $55 \pm 17$ & $0.06^{\mathbf{b}}$ \\
\hline & High-MAP & $50 \pm 8$ & $51 \pm 3$ & $61 \pm 6$ & $66 \pm 3$ & $66 \pm 5$ & $67 \pm 5$ & $60 \pm 20$ & \\
\hline $\mathrm{DO}_{2}$ & Septic-CG & $626 \pm 163$ & $592 \pm 158$ & & & & & $421 \pm 113$ & $<0.001^{\mathrm{a}}$ \\
\hline \multirow[t]{2}{*}{$\mathrm{mL} / \mathrm{min}$} & LoW-MAP & $526 \pm 118$ & $663 \pm 172$ & $682 \pm 100$ & $748 \pm 99$ & $712 \pm 93$ & $687 \pm 149$ & $687 \pm 149$ & $0.26^{b}$ \\
\hline & High-MAP & $541 \pm 92$ & $566 \pm 78$ & $749 \pm 118$ & $919 \pm 444$ & $862 \pm 201$ & $744 \pm 135$ & $702 \pm 173$ & \\
\hline $\mathrm{VO}_{2}$ & Septic-CG & $241 \pm 27$ & $267 \pm 44$ & & & & & $280 \pm 91$ & $0.293^{a}$ \\
\hline \multirow[t]{2}{*}{$\mathrm{mL} / \mathrm{min}$} & LOW-MAP & $277 \pm 46$ & $284 \pm 38$ & $281 \pm 28$ & $298 \pm 27$ & $282 \pm 35$ & $254 \pm 39$ & $254 \pm 39$ & $0.95^{b}$ \\
\hline & High-MAP & $269 \pm 50$ & $273 \pm 44$ & $280 \pm 49$ & $306 \pm 120$ & $276 \pm 34$ & $247 \pm 30$ & $256 \pm 38$ & \\
\hline CBFI, & Septic-CG & $6.7 \pm 1.3$ & $3.9 \pm 0.5$ & & & & & $2.8 \pm 0.6$ & $<0.001^{\mathrm{a}}$ \\
\hline \multirow[t]{2}{*}{$\mathrm{mL} / \mathrm{kg} / \mathrm{min}$} & LoW-MAP & $6.9 \pm 2.2$ & $4.9 \pm 2.1$ & $6.4 \pm 1.9$ & $8.5 \pm 2.1$ & $8.4 \pm 1.6$ & $8.0 \pm 1.6$ & $7.6 \pm 1.8$ & $0.55^{\mathrm{b}}$ \\
\hline & High-MAP & $5.4 \pm 1.6$ & $4.1 \pm 1.2$ & $5.6 \pm 1.6$ & $6.7 \pm 1.6$ & $6.8 \pm 1.8$ & $6.2 \pm 1.8$ & $5.8 \pm 2.0$ & \\
\hline FBFI, & Septic-CG & $3.5 \pm 0.7$ & $1.7 \pm 0.5$ & & & & & $1.2 \pm 0.3$ & $<0.001^{a}$ \\
\hline \multirow[t]{2}{*}{$\mathrm{mL} / \mathrm{kg} / \mathrm{min}$} & LoW-MAP & $3.9 \pm 1.6$ & $1.7 \pm 0.8$ & $2.2 \pm 0.4$ & $3.4 \pm 1.0$ & $3.8 \pm 0.6$ & $3.9 \pm 0.9$ & $3.7 \pm 1.0$ & $0.33^{\mathbf{b}}$ \\
\hline & High-MAP & $3.1 \pm 0.9$ & $1.4 \pm 0.6$ & $2.2 \pm 0.7$ & $3.2 \pm 1.0$ & $3.2 \pm 0.8$ & $3.4 \pm 0.7$ & $3.1 \pm 1.0$ & \\
\hline Arterial & Septic-CG & $0.7 \pm 0.1$ & $1.9 \pm 1.2$ & & & & & $4.1 \pm 2.0$ & $<0.001^{a}$ \\
\hline lactate, & LOW-MAP & $1.3 \pm 0.6$ & $1.0 \pm 0.4$ & $1.2 \pm 0.3$ & $1.1 \pm 0.4$ & $1.1 \pm 0.5$ & $0.9 \pm 0.2$ & $1.0 \pm 0.4$ & $0.19^{b}$ \\
\hline $\mathrm{mmol} / \mathrm{L}$ & High-MAP & $0.9 \pm 0.3$ & $1.0 \pm 0.2$ & $1.2 \pm 0.5$ & $1.2 \pm 0.5$ & $1.1 \pm 0.2$ & $1.1 \pm 0.3$ & $1.5 \pm 1.4$ & \\
\hline
\end{tabular}

Values are mean \pm SD. BL, baseline; EOP, end of observation period for the low-MAP and high-MAP groups (12 h after induction of peritonitis); RP, resuscitation period; END, end of the experiment (at 48 hours of resuscitation, or before death if earlier); MAP, mean arterial blood pressure; MPAP, mean pulmonary artery pressure; PAOP, pulmonary artery occlusion pressure; CVP, central venous pressure; SVRI, systemic vascular resistance index; $\mathrm{SvO}_{2}$, mixed venous oxygen saturation; $\mathrm{DO}_{2}$, systemic oxygen delivery; $\mathrm{VO}_{2}$, systemic oxygen consumption; $\mathrm{CBFI}$, carotid artery flow index; FBFI, femoral artery flow index; ${ }^{1} P$-value for ${ }^{\mathrm{a}}$ time-group interaction with repeated measures analysis of variance (ANOVA) including BL, EOP and END for all study groups (septic control (Septic-CG), Low-MAP and High-MAP groups); ${ }^{b}$ time-group interaction with repeated measures ANOVA including BL, EOP, RP 12 h, RP 24 h, RP 36 h and RP 48 h for the Low-MAP and High-MAP groups.

the effects of lower MAP targets $(50$ to $60 \mathrm{mmHg}$ ) on outcomes.

Jhanji et al. have shown that in a case series of sixteen patients with septic shock, increasing MAP from 60 to 90 mmHg using norepinephrine improved systemic oxygen delivery and cutaneous $\mathrm{PtO}_{2}$, did not affect sublingual microvascular flow and did not improve urinary output [5]. In our study, systemic oxygen delivery increased similarly in the low- and high-MAP groups, and systemic oxygen consumption was maintained in all groups. However, four out of seven animals (57\%) allocated to the low-MAP group, in comparison to none in the high-MAP group, presented with AKI at the end of study. In an experimental sepsis model using either endotoxemia or fecal peritonitis for $22 \mathrm{~h}$ with MAP $>70 \mathrm{mmHg}$, Benes et al. demonstrated a similar overall incidence of AKI of $50 \%$ [27]. It has been postulated that higher MAP levels (approximately 70 to $80 \mathrm{mmHg}$ ) may be necessary to decrease the development of AKI in patients with septic shock [17]. In our study, animals allocated to attainment 
Table 3 Inflammatory markers and organ function analysis

\begin{tabular}{|c|c|c|c|c|c|}
\hline Variable & Group & $\mathrm{BL}$ & EOP & End & $P$-value ${ }^{\pi}$ \\
\hline$\overline{I L-6,}$ & Septic-CG & $24 \pm 44$ & $781 \pm 410^{*}$ & $1785 \pm 819$ & $<0.001^{\mathrm{a}}$ \\
\hline \multirow[t]{2}{*}{$\mathrm{pg} / \mathrm{mL}$} & LOW-MAP & $20 \pm 26$ & $291 \pm 165$ & $57 \pm 59^{\#}$ & $0.61^{\mathbf{b}}$ \\
\hline & High-MAP & $5 \pm 10$ & $258 \pm 107$ & $95 \pm 177$ & \\
\hline TNF- $\alpha$, & Septic-CG & $102 \pm 75$ & $290 \pm 145^{*}$ & $410 \pm 160$ & $<0.001^{a}$ \\
\hline \multirow[t]{2}{*}{$\mathrm{pg} / \mathrm{mL}$} & LOW-MAP & $48 \pm 16$ & $149 \pm 55$ & $93 \pm 45^{\#}$ & $0.52^{\mathbf{b}}$ \\
\hline & High-MAP & $57 \pm 39$ & $130 \pm 89$ & $76 \pm 65$ & \\
\hline \multirow{3}{*}{$\begin{array}{l}\text { Hemoglobin, } \\
\text { mg/dL }\end{array}$} & Septic-CG & $9.4 \pm 0.8$ & $15.4 \pm 1.6$ & $14.7 \pm 1.8$ & $<0.001^{a}$ \\
\hline & LOW-MAP & $9.3 \pm 0.6$ & $14.7 \pm 0.7$ & $8.4 \pm 0.8$ & $0.014^{\mathbf{b}}$ \\
\hline & High-MAP & $9.2 \pm 0.4$ & $14.8 \pm 1.2$ & $10.0 \pm 1.2$ & $0.008^{c}$ \\
\hline \multirow{3}{*}{$\begin{array}{l}\text { Platelets, } \\
\times 10^{9} / \mathrm{L}\end{array}$} & Septic-CG & $296 \pm 97$ & $131 \pm 66^{*}$ & $98 \pm 53$ & $0.18^{\mathrm{a}}$ \\
\hline & Low-MAP & $255 \pm 48$ & $176 \pm 41$ & $115 \pm 42^{\#}$ & $0.19^{\mathbf{b}}$ \\
\hline & High-MAP & $323 \pm 102$ & $131 \pm 66$ & $98 \pm 53$ & \\
\hline \multirow{3}{*}{$\begin{array}{l}\text { White blood cell count, } \\
\times 10^{9} / \mathrm{L}\end{array}$} & Septic-CG & $14.0 \pm 1.6$ & $9.7 \pm 3.0^{*}$ & $10.7 \pm 2.8$ & $0.013^{a}$ \\
\hline & LOW-MAP & $18.4 \pm 5.2$ & $12.6 \pm 4.1$ & $16.9 \pm 5.2^{\#}$ & $0.014^{\mathbf{b}}$ \\
\hline & High-MAP & $16.9 \pm 3.5$ & $18.2 \pm 5.0$ & $18.9 \pm 4.7$ & $0.46^{c}$ \\
\hline Bands, & Septic-CG & $2.8 \pm 4.1$ & $38.1 \pm 8.2^{*}$ & $28.6 \pm 19.8$ & $0.021^{a}$ \\
\hline \multirow[t]{2}{*}{$\%$} & LOW-MAP & $11.6 \pm 15.6$ & $57.2 \pm 9.6$ & $23.4 \pm 18.2^{\#}$ & $0.05^{\mathbf{b}}$ \\
\hline & High-MAP & $0.8 \pm 0.7$ & $63.9 \pm 8.6$ & $27.4 \pm 10.0$ & $0.59^{c}$ \\
\hline Metamyelocytes, & Septic-CG & $0.0 \pm 0.0$ & $14.3 \pm 12.1^{*}$ & $12.5 \pm 7.5$ & $0.001^{\mathrm{a}}$ \\
\hline \multirow[t]{2}{*}{$\%$} & LoW-MAP & $0.0 \pm 0.0$ & $6.2 \pm 3.3$ & $1.9 \pm 3.6^{\#}$ & $0.93^{\mathbf{b}}$ \\
\hline & High-MAP & $0.0 \pm 0.0$ & $6.5 \pm 4.1$ & $1.4 \pm 3.0$ & \\
\hline Creatinine, & Septic-CG & $0.5(0.4,0.8)$ & $1.6(1.4,1.6)^{*}$ & $2.3(2.0,2.6)$ & $<0.03^{d}$ \\
\hline \multirow[t]{3}{*}{ mg/dl, median (IQR) } & LoW-MAP & $0.9(0.8,1.0)$ & $1.2(1.0,1.7)$ & $1.4(1.0,2.1)^{\#}$ & $0.295^{e}$ \\
\hline & High-MAP & $0.9(0.8,0.9)$ & $1.1(0.9,1.2)$ & $0.9(0.7,1.0)$ & $0.001^{f}$ \\
\hline & & & & & $0.021^{9}$ \\
\hline Total bilirubin, & Septic-CG & $1.6 \pm 1.2$ & $1.0 \pm 0.0^{*}$ & $1.1 \pm 0.4$ & $>0.60^{d}$ \\
\hline \multirow[t]{2}{*}{$\mu \mathrm{mol} / \mathrm{L}$} & Low-MAP & $1.5 \pm 1.1$ & $1.4 \pm 1.1$ & $1.6 \pm 1.5^{\#}$ & \\
\hline & High-MAP & $1.3 \pm 0.5$ & $1.1 \pm 0.4$ & $1.4 \pm 0.7$ & \\
\hline Creatine-kinase, & Septic-CG & & & $475(360,779)$ & $0.045^{f}$ \\
\hline \multirow[t]{2}{*}{$\mathrm{U} / \mathrm{L}$, median (IQR) } & LoW-MAP & & & $253(232,470)$ & $0.28^{\mathbf{9}}$ \\
\hline & High-MAP & & & $211(183,332)$ & \\
\hline Troponin, & Septic-CG & & & $0.015(0.013,0.032)$ & $0.091^{f}$ \\
\hline \multirow[t]{2}{*}{$\mu \mathrm{g} / \mathrm{L}$, median (IQR) } & LOW-MAP & & & $0.008(0.05,0.028) \mathbf{a}^{\#}$ & \\
\hline & High-MAP & & & $0.007(0.006,0.02)$ & \\
\hline
\end{tabular}

Values are mean \pm SD or median (IQR) where indicated. BL, baseline; EOP, end of observation period for Low-mean arterial pressure (MAP) and High-MAP groups ( $12 \mathrm{~h}$ after induction of peritonitis); END, end of the experiment (at 48 hours of resuscitation, or before death if earlier); ${ }^{\#}$ data available for seven animals; ${ }^{*}$ data available for five animals, in one measured after $24 \mathrm{~h}$ of $\mathrm{Pl}$, and in four after $18 \mathrm{~h}$ of Pl; ${ }^{\natural} P$-value for ${ }^{a}$ time-group interaction with repeated measures analysis of variance (ANOVA) including BL, EOP and END for all study groups (septic control (Septic-CG), Low-MAP and High-MAP groups); ${ }^{b}$ time-group

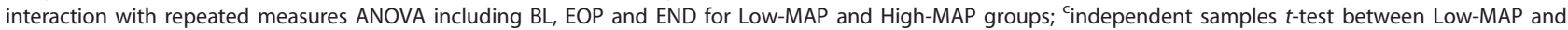
High-MAP groups at the END; ${ }^{d}$ time effect within each group (Septic-CG, Low-MAP and High-MAP) separately assessed by the non-parametric Friedman's test and including BL, EOP and END; ${ }^{\mathrm{e}}$ Kruskal-Wallis test at the EOP; ${ }^{\mathrm{f}}$ Kruskal-Wallis test at the End; ${ }^{\mathrm{g}}$ Mann-Whitney U-test between Low-MAP and High-MAP groups at the END.

of MAP between 75 to $85 \mathrm{mmHg}$ received higher amounts of both fluids and norepinephrine in comparison to animals allocated to the low-MAP group. We found a significant correlation between percentage of time spent with blood pressure $>60 \mathrm{mmHg}$ and plasma creatinine in the end of the study, but not between the amount of administered fluids and plasma creatinine. It seems unlikely therefore, that more fluid per se would have been beneficial in the low-MAP group.
Data from experimental [24,28] and clinical studies [15,29-37] have shown that therapeutic attempts, including administration of fluids and vasopressors to restore hemodynamic stability during sepsis may be associated with poor outcomes. In critically ill septic and non-septic patients, the cumulative positive fluid balance has been associated with a worse outcome [29-31,34,36,37], and the administration of catecholamines, particularly at higher doses, was associated with derangements in regional blood 


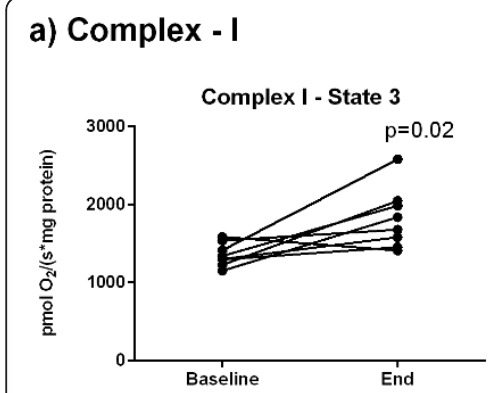

\section{b) Complex - II}
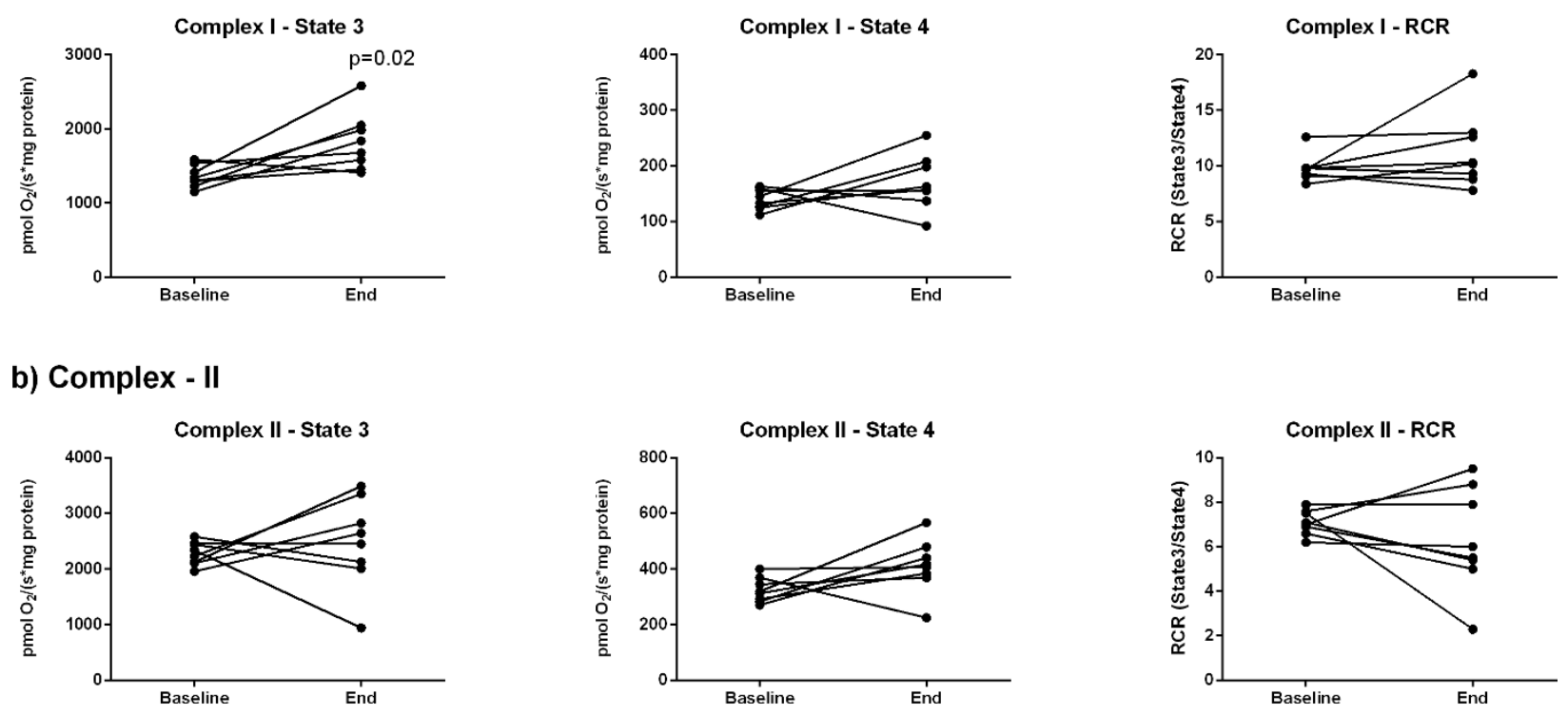

\section{c) Complex - IV}

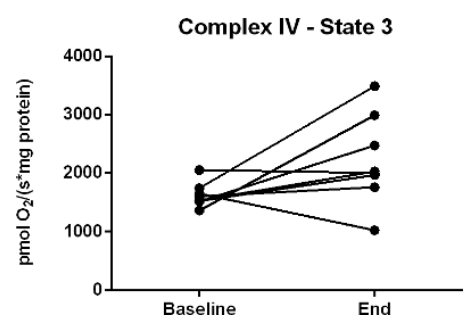

Figure 3 Isolated skeletal muscle mitochondrial respiration during unresuscitated sepsis. Complex I-, II- and IV-isolated skeletal muscle mitochondrial respiration in septic control animals from baseline to end (represented by connecting lines for each pig, $\mathrm{n}=8$ ). State 3 and State 4 oxygen consumption is expressed as pmol/second/mg protein. State 3, active respiration after addition of ADP; State 4, respiration after consumption of ADP. The ratio between State 3 and State 4 was calculated as the respiratory control ratio (RCR; state $3 /$ state 4$)$. ${ }^{*} P=0.02$, paired $t$-test.

flow $[7,8]$, adverse side effects [33,35] and increased likelihood of death $[15,32,35]$. In our experimental model such effects were not observed or observable. However, whether renal hyperfiltration as a result of high blood pressure and volume load may cause delayed harm to septic kidneys should be addressed in further studies.

Sepsis may result in various changes in mitochondrial enzyme activity and tissue ATP. Muscle complex-I activity decreased and complex-IV activity have been found to be increased in patients who subsequently died in sepsis [13], whereas an acute endotoxin challenge is reported to increase muscle complex-I activity in healthy volunteers [38]. Reduced tissue ATP levels have been observed in various tissues and sepsis models, but not consistently. Quadriceps muscle ATP was found to be reduced in non-survivors of sepsis but not in survivors [13]. In severe sepsis, intercostal muscle ATP is reported as normal, while leg muscle ATP is decreased
[39]. In experimental sepsis decreased ATP content has been reported in the rat liver and the kidney but not in the muscle $[40,41]$, and in the liver in porcine bacterial sepsis [42]. In porcine endotoxemia, reduced ATP content in the intestinal mucosa but not muscularis [43], as well as unchanged intestinal wall ATP has been reported [44].

Instead of respiratory chain enzyme activities, we assessed mitochondrial respiration using substrate-induced maximal oxygen consumption. We found no signs of impaired mitochondrial respiration in the muscle-isolated mitochondria or in the permeabilized muscle fibers, and the muscle ATP levels remained unchanged, even in the untreated septic group, with $100 \%$ mortality. In contrast, complex I-dependent state 3 respiration of isolated muscle mitochondria increased in untreated sepsis, and complex IV-dependent state 3 respiration increased in the permeabilized muscle fibers in the resuscitated septic groups. 


\section{a) Complex - I}
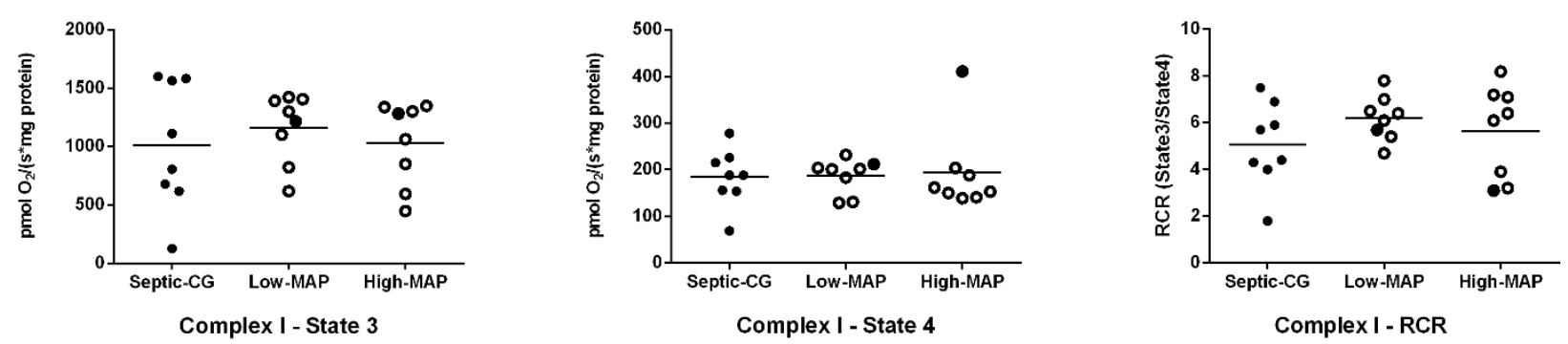

\section{b) Complex - II}
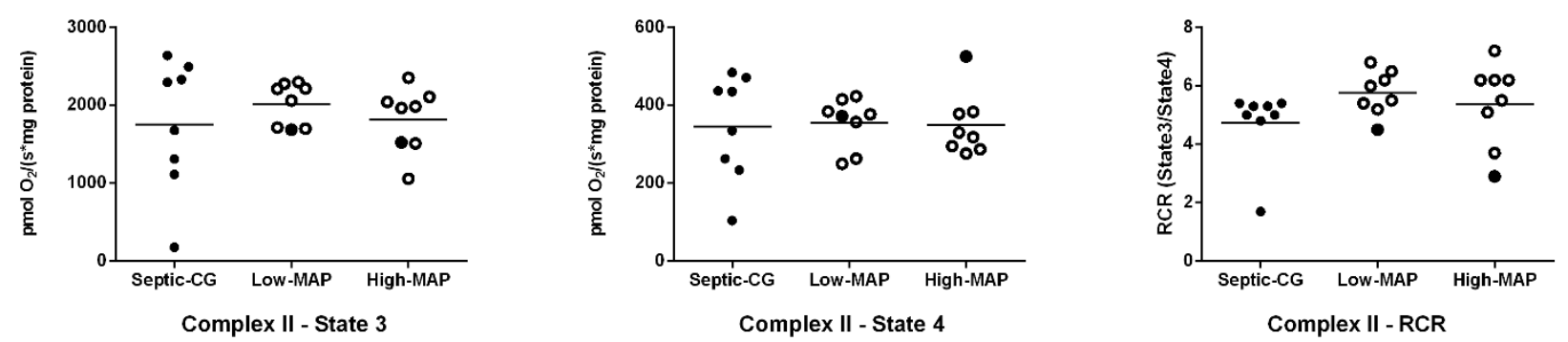

c) Complex - IV

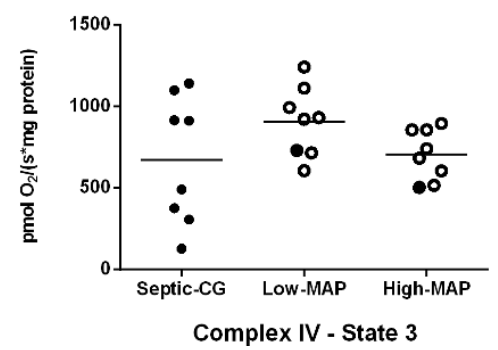

Figure 4 Isolated liver mitochondrial respiration. Comparison of isolated liver mitochondrial respiration in septic control animals and septic animals resuscitated to low-mean arterial pressure (MAP) and high-MAP targets $(n=8)$. State 3 and 4 oxygen consumption is expressed as $\mathrm{pmol} / \mathrm{second} / \mathrm{mg}$ protein. No significant differences were found between the groups $(P>0.05$, one-way analysis of variance). Horizontal lines represent mean values. Filled circles represent animals that died early. State 3, active respiration after addition of ADP; State 4, respiration after consumption of ADP; RCR, respiratory control ratio (oxygen consumption of State 3/State 4).

In the presence of unchanged RCR and muscle ATP content, this may be related to increased metabolic activity and increased ADP transport into mitochondria [45]. One mechanism which may help to maintain ATP levels in sepsis is increased phosphocreatine breakdown, which provides fuel for various cellular processes [41].

We observed previously that delay in starting resuscitation was associated with decreased muscle ATP levels at the time of death [28], in contrast to the well-preserved muscle ATP levels in the present study. Deaths in that study occurred later, after a period of resuscitation, whereas in the present study the deaths occurred earlier, and all except two resuscitated animals survived. The well-preserved muscle ATP levels in the dying animals in the present study are likely to be related to the earlier death.
Resuscitation to a low compared to a high MAP target had no effect on isolated skeletal muscle mitochondrial respiration, or on isolated liver mitochondrial respiration, suggesting that neither higher organ perfusion pressure nor increased vasopressor load had an effect. We previously observed that the need to support hemodynamics with norepinephrine in porcine fecal peritonitis of shorter duration was associated with lower hepatic complex IIdependent state 4 respiration, while state 3 and RCR were not altered [20]. We also found in endotoxemic pigs that norepinephrine improved hepatic mitochondrial respiratory efficiency [46]. Similarly, norepinephrine tended to increase ileal wall mitochondrial complex-I activity in an endotoxemic sheep model [47]. The lack of difference in the liver mitochondrial respiration between the groups in the present study suggests that the effect of norepinephrine 


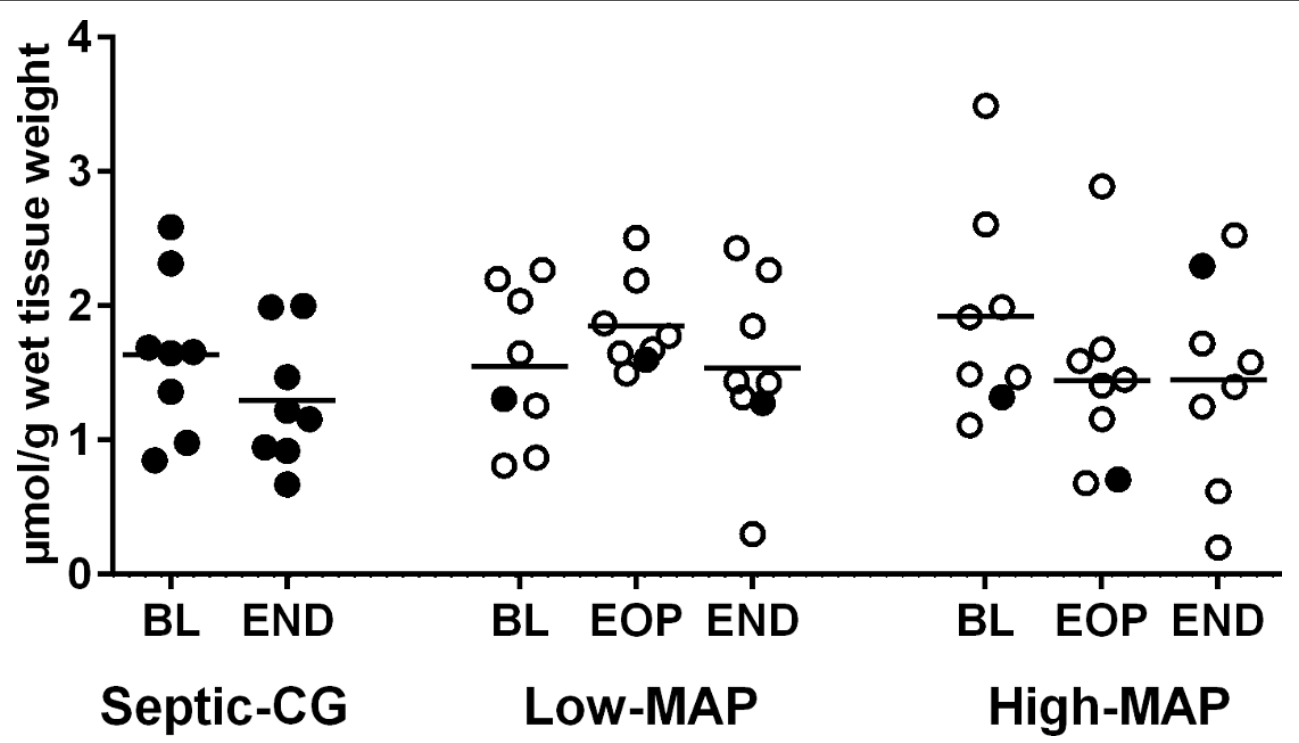

Figure 5 Skeletal muscle tissue ATP concentrations in septic controls and animals resuscitated to low-mean arterial pressure (MAP) and high-MAP targets. The black horizontal bars represent the mean values. Filled circles represent animals that died early. $P>0.05$ for all comparisons. BL, baseline; EOP, end of observation period; END, end of the experiment (at $48 \mathrm{~h}$ of resuscitation, or before death if earlier).

on the liver is model-dependent or related to the duration of exposure.

Our study has limitations. We evaluated only two ranges of MAP for the initial resuscitation of severe sepsis and septic shock. Second, respiration rates were not normalized to the citrate synthase activity (mitochondrial content) [48]. Reduced skeletal muscle mitochondrial enzyme activity has been observed in patients with sepsis and multiple organ failure if expressed per wet muscle weight, but not if normalized to citrate synthase activity, a marker of mitochondrial content [39]. This may suggest decreased mitochondrial mass rather than specific inhibition of the mitochondrial enzymes in sepsis. Consequently, our finding of increased permeabilized muscle fibers complex IV-respiration may be due to variations in mitochondrial content. Third, the final skeletal muscle and liver samples in the animals that died before completing the 48-hour resuscitation period were taken when MAP approached $30 \mathrm{mmHg}$, and therefore may potentially reflect a neardeath state rather than non-confounded differences between the study groups. Fourth, we did not evaluate the microcirculation in animals resuscitated with a low MAP target. It is possible that lower MAP is associated with decreased microvascular blood flow [49]. Fifth, we studied a small number of animals per group. Therefore, there is a risk of a type II error, and we cannot exclude true, small, undetected differences between groups. Finally, in this model of fecal peritonitis in young, healthy pigs, MAP thresholds may not have the same importance for tissue oxygenation as in older septic patients.

\section{Conclusions}

In this abdominal sepsis model with $100 \%$ mortality unless treatment is installed, the MAP targets of 50 to $60 \mathrm{mmHg}$ versus 75 to $85 \mathrm{mmHg}$ during resuscitation did not result in differences in the inflammatory response skeletal muscle ATP content, or in mitochondrial respiration. While targeting a lower MAP was associated with increased incidence of AKI, targeting a higher MAP resulted in increased net positive fluid balance and vasopressor load during resuscitation. The long-term effects on kidney function of using lower MAP targets, and whether the resulting increased fluid balance and vasopressor load using higher MAP targets are of relevance for recovery after initial resuscitation, need to be evaluated in further studies.

\section{Key messages}

- Targeting a MAP between 50 and $60 \mathrm{mmHg}$ in septic shock was associated with increased incidence of AKI.

- Targeting a higher MAP (75 to $85 \mathrm{mmHg}$ ) during resuscitation did not ameliorate the inflammatory response and resulted in increased net positive fluid balance and vasopressor load during resuscitation.

- MAP targets did not modify the inflammatory response, the skeletal muscle ATP content or mitochondrial respiration.

- Unresuscitated septic animals died, with increased plasma levels of inflammatory markers, increased maximal skeletal muscle complex-I mitochondrial respiration, and with preserved skeletal muscle ATP content. 


\section{Additional material}

\section{Additional file 1: Word text file containing additional information} about the methods, along with related references.

Additional file 2: Word file containing four tables and three figures.

Table S1 indicates the percentage of time spent at different blood pressure ranges. Table $\mathbf{S} 2$ describes the acid-base-balance parameters and respiratory system variables. Table S3 gives permeabilized skeletal muscle fibers maximal mitochondrial respiration (state 3 ) in animals resuscitated to low and high-mean arterial pressure (MAP) targets. Table S4 lists permeabilized skeletal muscle fibers maximal mitochondrial respiration (state 3 ) in the septic control group. Figure S1 shows the MAP and norepinephrine administration over the study period in animals randomized to the low and high-MAP groups. Figure S2 shows a scatter plot of plasma creatinine in the three study groups. Figure S3 shows isolated skeletal muscle mitochondrial respiration in animals resuscitated to low and high MAP.

\section{Abbreviations}

AKI: acute kidney injury; ANOVA: analysis of variance; BL: baseline; CBFI: carotid artery flow index; CVP: central venous pressure; $\mathrm{DO}_{2}$ : systemic oxygen delivery; EOP: end of observation period (12 hours after peritonitis induction); $\mathrm{FBFl}$ : femoral artery flow index; $\mathrm{FiO}_{2}$ : fractional inspiratory oxygen concentration; G50\%: glucose 50\%; high-MAP: resuscitation targeting mean arterial pressure between 75 and $85 \mathrm{mmHg}$; IL-6: plasma interleukin-6; lowMAP: resuscitation targeting mean arterial pressure between 50 and 60 mmHg; MAP: mean arterial blood pressure; MPAP: mean pulmonary artery pressure; $\mathrm{PaCO}_{2}$ : arterial carbon dioxide partial pressure; PAOP: pulmonary artery occlusion pressure; PEEP: positive end-expiratory pressure; RCR: respiratory control ratio; RP: resuscitation period; septic-CG: septic control group; $\mathrm{SVO}_{2}$ : mixed venous oxygen saturation; SVRI: systemic vascular resistance index; TNF-a: tumor necrosis factor-a; $\mathrm{VO}_{2}$ : systemic oxygen consumption.

\section{Authors' contributions}

TDC, JT and SMJ devised the study protocol. TDC, MV, SD and SMJ initiated and performed all animal experiments. MV and SD performed mitochondriarelated experiments. TDC, MV and SMJ analyzed the data. TDC and MV wrote the first manuscript draft. SMJ, JT and ES critically revised the manuscript. All authors approved the final manuscript.

\section{Competing interests}

The authors declare that they have no competing interests.

\section{Acknowledgements}

Financial support was provided by the Swiss National Science Foundation (Grant number 32003B 127619). We thank Michael Lensch, Olgica Beslac, Daniel Mettler, Daniel Zalokar, Natalie Araya Araya, Torsten Konrad, Colette Boillat, Sandra Nansoz, Matthias Hänggi, Tobias Merz, Stephan Bloechlinger, Christian Schmittinger, Christian Torgensen, Stepani Bendel, Reto Etter, Jan Wiegand, Fritz Daudel, David Berger, Lukas Brander, Sarah Wagner and Rahel Kindler for their assistance during the experiments. The work was performed in the Experimental Surgery Unit of the University of Bern, Bern, Switzerland.

\section{Author details}

'Department of Intensive Care Medicine, Inselspital, Bern University Hospital and University of Bern, Freiburgstrasse 10, Bern, CH-3010, Switzerland. ${ }^{2}$ Intensive Care Unit, Hospital Israelita Albert Einstein, Av Albert Einstein 627/ 701, São Paulo, 05651-901, Brazil.

Received: 14 September 2012 Revised: 14 November 2012 Accepted: 25 January 2013 Published: 30 January 2013

\section{References}

1. Guyton AC, Hall JE: Textbook of Medical Physiology Philadelphia: Saunders; 2005.

2. Dellinger RP, Levy MM, Carlet JM, Bion J, Parker MM, Jaeschke R, Reinhart K, Angus DC, Brun-Buisson C, Beale R, Calandra T, Dhainaut JF, Gerlach H,
Harvey M, Marini JJ, Marshall J, Ranieri M, Ramsay G, Sevransky J, Thompson BT, Townsend S, Vender JS, Zimmerman JL, Vincent JL: Surviving Sepsis Campaign: international guidelines for management of severe sepsis and septic shock: 2008. Crit Care Med 2008, 36:296-327.

3. LeDoux D, Astiz ME, Carpati CM, Rackow EC: Effects of perfusion pressure on tissue perfusion in septic shock. Crit Care Med 2000, 28:2729-2732.

4. Bourgoin A, Leone M, Delmas A, Garnier F, Albanèse J, Martin C: Increasing mean arterial pressure in patients with septic shock: effects on oxygen variables and renal function. Crit Care Med 2005, 33:780-786.

5. Jhanji S, Stirling S, Patel N, Hinds CJ, Pearse RM: The effect of increasing doses of norepinephrine on tissue oxygenation and microvascular flow in patients with septic shock. Crit Care Med 2009, 37:1961-1966.

6. Thooft A, Favory R, Salgado DR, Taccone FS, Donadello K, De Backer D, Creteur J, Vincent JL: Effects of changes in arterial pressure on organ perfusion during septic shock. Crit Care 2011, 15:R222.

7. Di Giantomasso D, May CN, Bellomo R: Norepinephrine and vital organ blood flow during experimental hyperdynamic sepsis. Intensive Care Med 2003, 29:1774-1781.

8. Di Giantomasso D, Bellomo R, May CN: The haemodynamic and metabolic effects of epinephrine in experimental hyperdynamic septic shock. Intensive Care Med 2005, 31:454-462.

9. Träger $K$, Radermacher $P$, Leverve $X$ : The adrenergic coin: perfusion and metabolism. Intensive Care Med 2003, 29:150-153.

10. Porta F, Bracht H, Weikert C, Beck M, Takala J, Brandt S, Hiltebrand LB, Jakob SM: Effects of endotoxin and catecholamines on hepatic mitochondrial respiration. Inflammation 2009, 32:315-321.

11. Singer M, Brealey D: Mitochondrial dysfunction in sepsis. Biochem Soc Symp 1999, 66:149-166.

12. Crouser ED, Julian MW, Dorinsky PM: Ileal VO(2)-O(2) alterations induced by endotoxin correlate with severity of mitochondrial injury. Am J Respir Crit Care Med 1999, 160:1347-1353.

13. Brealey D, Brand M, Hargreaves I, Heales S, Land J, Smolenski R, Davies NA, Cooper CE, Singer M: Association between mitochondrial dysfunction and severity and outcome of septic shock. Lancet 2002, 360:219-223.

14. Takala J: Should we target blood pressure in sepsis? Crit Care Med 2010, 38:S613-S619.

15. Dünser MW, Ruokonen E, Pettilä V, Ulmer H, Torgersen C, Schmittinger CA Jakob S, Takala J: Association of arterial blood pressure and vasopressor load with septic shock mortality: a post hoc analysis of a multicenter trial. Crit Care 2009, 13:R181.

16. Sevransky JE, Nour S, Susla GM, Needham DM, Hollenberg S, Pronovost P: Hemodynamic goals in randomized clinical trials in patients with sepsis: a systematic review of the literature. Crit Care 2007, 11:R67.

17. Badin J, Boulain T, Ehrmann S, Skarzynski M, Bretagnol A, Buret J, BenzekriLefevre D, Mercier E, Runge I, Garot D, Mathonnet A, Dequin PF, Perrotin D: Relation between mean arterial pressure and renal function in the early phase of shock: a prospective, explorative cohort study. Crit Care 2011, 15:R135.

18. Dünser MW, Takala J, Ulmer H, Mayr VD, Luckner G, Jochberger S, Daudel F, Lepper P, Hasibeder WR, Jakob SM: Arterial blood pressure during early sepsis and outcome. Intensive Care Med 2009, 35:1225-1233.

19. Varpula M, Tallgren M, Saukkonen K, Voipio-Pulkki LM, Pettilä V: Hemodynamic variables related to outcome in septic shock. Intensive Care Med 2005, 31:1066-1071.

20. Vuda M, Brander L, Schröder R, Jakob SM, Takala J, Djafarzadeh S: Effects of catecholamines on hepatic and skeletal muscle mitochondrial respiration after prolonged exposure to faecal peritonitis in pigs. Innate Immun 2012, 18:217-230.

21. Mehta RL, Kellum JA, Shah SV, Molitoris BA, Ronco C, Warnock DG, Levin A: Acute Kidney Injury Network: report of an initiative to improve outcomes in acute kidney injury. Crit Care 2007, 11:R31.

22. Marx G, Pedder S, Smith L, Swaraj S, Grime S, Stockdale H, Leuwer M: Attenuation of capillary leakage by hydroxyethyl starch (130/0.42) in a porcine model of septic shock. Crit Care Med 2006, 34:3005-3010.

23. Hiltebrand LB, Krejci V, Jakob SM, Takala J, Sigurdsson GH: Effects of vasopressin on microcirculatory blood flow in the gastrointestinal tract in anesthetized pigs in septic shock. Anesthesiology 2007, 106:1156-1167.

24. Brandt S, Regueira T, Bracht H, Porta F, Djafarzadeh S, Takala J, Gorrasi J, Borotto E, Krejci V, Hiltebrand LB, Bruegger LE, Beldi G, Wilkens L, Lepper PM, Kessler U, Jakob SM: Effect of fluid resuscitation on mortality 
and organ function in experimental sepsis models. Crit Care 2009, 13: R186.

25. Rosário AL, Park M, Brunialti MK, Mendes M, Rapozo M, Fernandes D, Salomão R, Laurindo FR, Schettino GP, Azevedo LC: SvO(2)-guided resuscitation for experimental septic shock: effects of fluid infusion and dobutamine on hemodynamics, inflammatory response, and cardiovascular oxidative stress. Shock 2011, 36:604-612.

26. Chvojka J, Sykora R, Krouzecky A, Radej J, Varnerova V, Karvunidis T, Hes O, Novak I, Radermacher P, Matejovic M: Renal haemodynamic, microcirculatory, metabolic and histopathological responses to peritonitis-induced septic shock in pigs. Crit Care 2008, 12:R164.

27. Benes J, Chvojka J, Sykora R, Radej J, Krouzecky A, Novak I, Matejovic M: Searching for mechanisms that matter in early septic acute kidney injury: an experimental study. Crit Care 2011, 15:R256.

28. Corrêa TD, Vuda M, Blaser AR, Takala J, Djafarzadeh S, Dünser MW, Silva E, Lensch M, Wilkens L, Jakob SM: Effect of treatment delay on disease severity and need for resuscitation in porcine fecal peritonitis. Crit Care Med 2012, 40:2841-2849.

29. Wiedemann HP, Wheeler AP, Bernard GR, Thompson BT, Hayden D, deBoisblanc B, Connors AF Jr, Hite RD, Harabin AL: Comparison of two fluid-management strategies in acute lung injury. N Engl J Med 2006, 354:2564-2575.

30. Uchino S, Bellomo R, Morimatsu H, Sugihara M, French C, Stephens D, Wendon J, Honore P, Mulder J, Turner A: Pulmonary artery catheter versus pulse contour analysis: a prospective epidemiological study. Crit Care 2006, 10:R174.

31. Rosenberg AL, Dechert RE, Park PK, Bartlett RH: Review of a large clinical series: association of cumulative fluid balance on outcome in acute lung injury: a retrospective review of the ARDSnet tidal volume study cohort. J Intensive Care Med 2009, 24:35-46.

32. Póvoa PR, Carneiro AH, Ribeiro OS, Pereira AC: Influence of vasopressor agent in septic shock mortality. Results from the Portuguese Community-Acquired Sepsis Study (SACiUCI study). Crit Care Med 2009, 37:410-416.

33. De Backer D, Biston P, Devriendt J, Madl C, Chochrad D, Aldecoa C, Brasseur A, Defrance P, Gottignies P, Vincent JL: Comparison of dopamine and norepinephrine in the treatment of shock. N Engl J Med 2010, 362:779-789.

34. Boyd JH, Forbes J, Nakada TA, Walley KR, Russell JA: Fluid resuscitation in septic shock: a positive fluid balance and elevated central venous pressure are associated with increased mortality. Crit Care Med 2011, 39:259-265.

35. De Backer D, Aldecoa C, Njimi H, Vincent JL: Dopamine versus norepinephrine in the treatment of septic shock: A meta-analysis*. Crit Care Med 2012, 40:725-730.

36. de Almeida JP, Palomba H, Galas FR, Fukushima JT, Duarte FA, Nagaoka D, Torres V, Yu L, Vincent JL, Auler JO Jr, Hajjar LA: Positive fluid balance is associated with reduced survival in critically ill patients with cancer. Acta Anaesthesiol Scand 2012, 56:712-717.

37. Bellomo R, Cass A, Cole L, Finfer S, Gallagher M, Lee J, Lo S, McArthur C, McGuiness S, Norton R, Myburgh J, Scheinkestel C, Su S: An observational study fluid balance and patient outcomes in the Randomized Evaluation of Normal vs. Augmented Level of Replacement Therapy trial. Crit Care Med 2012, 40:1753-1760

38. Fredriksson K, Fläring U, Guillet C, Wernerman J, Rooyackers O: Muscle mitochondrial activity increases rapidly after an endotoxin challenge in human volunteers. Acta Anaesthesiol Scand 2009, 53:299-304.

39. Fredriksson $K$, Hammarqvist $F$, Strigård $K$, Hultenby $K$, Ljungqvist $O$, Wernerman J, Rooyackers O: Derangements in mitochondrial metabolism in intercostal and leg muscle of critically ill patients with sepsis-induced multiple organ failure. Am J Physiol Endocrinol Metab 2006, 291: E1044-E1050.

40. Chaudry $\mathbb{H}$, Wichterman KA, Baue AE: Effect of sepsis on tissue adenine nucleotide levels. Surgery 1979, 85:205-211.

41. Jacobs DO, Kobayashi T, Imagire J, Grant C, Kesselly B, Wilmore DW: Sepsis alters skeletal muscle energetics and membrane function. Surgery 1991, 110:318-325.

42. Hart DW, Gore DC, Rinehart AJ, Asimakis GK, Chinkes DL: Sepsis-induced failure of hepatic energy metabolism. J Surg Res 2003, 115:139-147.

43. Revelly JP, Liaudet L, Frascarolo P, Joseph JM, Martinet O, Markert M: Effects of norepinephrine on the distribution of intestinal blood flow and tissue adenosine triphosphate content in endotoxic shock. Crit Care Med 2000, 28:2500-2506.

44. Nagelschmidt M, Holthausen U, Goost H, Fu ZX, Minor T, Troidl H, Neugebauer $E$ : Evaluation of the effects of a pneumoperitoneum with carbon dioxide or helium in a porcine model of endotoxemia. Langenbecks Arch Surg 2000, 385:199-206.

45. Taylor DE, Kantrow SP, Piantadosi CA: Mitochondrial respiration after sepsis and prolonged hypoxia. Am J Physiol 1998, 275:L139-L144.

46. Regueira T, Bänziger B, Djafarzadeh S, Brandt S, Gorrasi J, Takala J, Lepper PM, Jakob SM: Norepinephrine to increase blood pressure in endotoxaemic pigs is associated with improved hepatic mitochondrial respiration. Crit Care 2008, 12:R88.

47. Andersson A, Rundgren M, Kalman S, Rooyackers O, Brattstrom O, Oldner A, Eriksson S, Frithiof R: Gut microcirculatory and mitochondrial effects of hyperdynamic endotoxaemic shock and norepinephrine treatment. $\mathrm{Br}$ J Anaesth 2012, 108:254-261.

48. Sperl W, Skladal D, Gnaiger E, Wyss M, Mayr U, Hager J, Gellerich FN: High resolution respirometry of permeabilized skeletal muscle fibers in the diagnosis of neuromuscular disorders. Mol Cell Biochem 1997, 174:71-78.

49. Ince C: The microcirculation is the motor of sepsis. Crit Care 2005, 9(Suppl 4):S13-S19.

doi:10.1186/cc12495

Cite this article as: Corrêa et al:: Increasing mean arterial blood pressure in sepsis: effects on fluid balance, vasopressor load and renal function. Critical Care 2013 17:R21.

\section{Submit your next manuscript to BioMed Central and take full advantage of:}

- Convenient online submission

- Thorough peer review

- No space constraints or color figure charges

- Immediate publication on acceptance

- Inclusion in PubMed, CAS, Scopus and Google Scholar

- Research which is freely available for redistribution 